УКРАЇНСЬКА МОВА I СУЧАСНІСТЬ: ФОРМУВАННЯ МОВЛЕННЄВОЇ КОМПЕТЕНТНОСТІ СТУДЕНТІВ

\title{
UKRAINIAN LANGUAGE AND MODERNITY: FORMING STUDENTS SPEECH COMPETENCY
}

Аналіз сучасних тенденцій розвитку вищої освіти в Україні показав, що актуальним залишається питання забезпечення конститучійного статусу державної мови. Виявлено, що в багатьох закладах освіти багато природничих дисциплін ідосі викладаються російською мовою через відсутність розробленої технічної термінології українською мовою та обмежену кількість підручників для викладання технічних предметів. Автори наголошують, що в умовах сьогодення важливе використання українсько мови без профанації в усіх сорерах суспільства і саме вища освіта має бути першою, оскільки готує студентів із різних галузей знань та спеціальностей.

У зв'язку з прийняттям нових законів про статус та фрункціонування української мови як державної, а також появою нової редакції Українського правопису доведено, що фрормування мовленнєвої компетентності майбутнього фрахівця $\epsilon$ і залишається одним з основних завдань закладів вищої освіти. Уточнено та конкретизовано сутність поняття «мовленнєва компетентність», яке автори пропонують розглядати як практичне володіння державною мовою та основами культури усного і писемного мовлення в різних сорерах спілкування.

Одним із найдієвіших засобів фрормування у студентів мовленнєвої компетентності автори вбачають застосування ігрових технологій, які в аспекті дослідження розуміють як форму організації навчального процесу, в якій обов'язковою вимогою виступає активна та рівноправна взаємодія усіх учасників такого процесу, спрямована на виховання й навчання під час гри й опанування різних соціальних ролей, із метою збагачення індивідуального та суспільного досвіду.

На основі запропонованих методів удосконалення умінь і навичок студентів у різних видах мовної діяльності аргументовано застосування ігрових технологій під час вивчення дисципліни «Українська мова (за профресійним спрямуванням)» для фрормування у студентів мовленнєвої компетентності. Виокремлено переваги використання інтерактивних технологій під час підготовки майбутніх фахівців у ЗВО.

Ключові слова: мова, мовна компетент ність, мовленнєва компетентність, інтерактивні технології навчання.
Analysis of modern trends in higher education in Ukraine has shown, that the issue of ensuring the constitutional status of the state language remains relevant. Found that in most educational institutions many scientific disciplines are still taught in Russian, in the absence of technical terminology developed by the Ukrainian language and a limited number of textbooks for teaching technical subjects.

The authors emphasize that in today's context it is important to use Ukrainian without profanity in all spheres of society and that higher education should be the first because it prepares students from different fields of knowledge and specialties.

Due to the adoption of new laws on the status and functioning of the Ukrainian language as a state language, as well as the emergence of a new version of the Ukrainian spelling, it is proved that the formation of the speech com petence of the future specialist show up and remains one of the main tasks of higher education institutions.

Clarified and fleshed essence of the concept "speech competence", which the authors propose to consider as practical knowledge of the state language and the basics of the culture of oral and written speech in various fields of communication. One of the most effective means of forming students' speech competence is the use of game technologies, which in the aspect of research is understood as a form of organization of the educational process, in which the active and equal interaction of all participants of such process, aimed at education and learning during play, is a mandatory requirement. and mastering different social roles to enrich individual and social experiences.

On the basis of the proposed methods of improving students 'skills in various types of language activity, was substantiated the using of game technologies in the study of the discipline "Ukrainian language (by professional direction)" for forming students speech competence. Singled out the benefits of using interactive technologies in the training of future professionals in higher education.

Key words: language, language competence, speech competence, interactive learning technologies.
Постановка проблеми у загальному вигляді. «Кожен громадянин України зобов'язаний володіти державною мовою», - зазначено в ст. 6, п. 1 ЗУ «Про забезпечення фрункціонування української мови як державної», який набув чинності 16 липня 2019 р. Ґрунтуючись на Декларації про державний суверенітет України від 16 липня 1990 р. та схваленому Всеукраїнським референдумом 1 грудня 1991 р. Акті проголошення незалежності України від 24 серпня 1991 р., керуючись Конституцією України, діючи відповідно до Рішення Конституційного Суду України від 14 грудня 1999 р. № 10-рп/99, зважаючи на Концепцію державної мовної політики, затверджену Указом Президента України від 15 лютого 2010 р. № 161/2010, ЗУ «Про забезпечення фрункціонування української мови як державної» визначає українську мову єдиною державною та офріційною мовою нашої країни.

Таким чином, фрормування мовленнєво компетентного здобувача вищої освіти України залишається одним 3 основних завдань закладів вищої освіти.

Аналіз останніх досліджень і публікацій. Проблему використання української мови в ЗВО 
України досліджували провідні вітчизняні науковці, зокрема, І. Лопушинський, І. Магрицька, Л. Мацько, А. Пономаренко, М. Пентилюк, О. Пометун, М. Плющ, А. Свідзинський, С. Єрмоленко, І. Ющук та ін.

Різні аспекти мовленнєвої компетентності досліджували І. Бех, О. Біляєв, М. Вашуленко, І. Ґудзик, Ю. Завалевський, Т. Ладижинська, Л. Мацько, В. Мельничайко, Л. Паламар, М. Пентилюк, Л. Скуратівський, Л. Струганець, Г. Шелехова тощо.

Сутність та специфіка ігрових методів були предметом розгляду таких науковців: І. Андрійко, Г. Бородіна, В. Буркова, Л. Виготський, В. Гриньова, Г. Гусак, В. Демидова, Л. Журба, І. Зварич, Т. Іванцова, А. Конишева, О. Колесникова, Т. Спірідонова, А. Пассов, М. Стронін, І. Жучкова, Г. Фролова, Т. Шкваріна та ін.

Виділення невирішених раніше частин загальної проблеми. Незважаючи на велику кількість досліджень, присвячених проблемі мовленнєвої компетентності здобувачів вищої освіти, аспект використання ігрових методів для удосконалення комунікативних умінь і навичок залишився мало дослідженим.

Мета статті - дослідити особливості фрормування у студентів мовленнєвої компетентності шляхом використання інтерактивних технологій навчання, з обґрунтуванням ефрективності їх використання.

Виклад основного матеріалу. На перший погляд, актуальність пропонованого дослідження може здатися не злободенною (двадцять вісім років Україна - незалежна держава), проте відкритим залишається питання використання української мови хоча б в таких сорерах життя суспільства, як освіта й наука. У нас і досі є російськомовні школи, в яких згідно з чинним законодавством вчителі зобов'язані викладати всі предмети українською мовою лише з 2020 р. У багатьох закладах вищої освіти багато природничих дисциплін і досі викладаються російською мовою, а МОН на основі звернень представників громадських організацій і окремих громадян у листах (щодо застосування державної мови) звертається до керівників закладів освіти 3 рекомендаціями та проханнями (!) забезпечити виконання законодавства України в частині застосування державної мови в освітньому процесі.

В умовах сьогодення важливе використання української мови без профранації в усіх сорерах суспільства, і саме вища освіта має бути першою, оскільки готує майбутніх фахівців із різних галузей знань та спеціальностей. Так, фрормування мовленнєво компетентного майбутнього фрахівця $€ \mathrm{i}$ залишається одним з основних завдань закладів вищої освіти.

І нині актуальною, на нашу думку, залишається наукова праця І. Лопушинського «Забезпечення конституційного статусу державної мови у вищій школі України сьогодення як належна перспектива мовленнєвої фрахової практики», в якій автор пише: «Неприпустимо, коли керівництво і професори ВН3, насамперед національних, послуговуються в своїй роботі мовою сусідньої держави. У зв'язку 3 такою їхньою позицією у ВНЗ виникає питання, якою мовою читати предмет - українською чи російською. А деколи викладач і не цікавиться думкою студентів, а просто читає курс російською мовою» [5]. Автор причину такого поводження викладачів пояснює відсутністю розробленої технічної термінології українською мовою та підручників для викладання технічних предметів.

Позитивним в умовах сьогодення вбачаємо появу нової редакції Українського правопису, затверджену Кабінетом міністрів 22 травня 2019 р., 3 метою забезпечення конституційних положень про державний статус української мови та унісрікації вживання правописних норм.

Насамперед вважаємо за доцільне розкрити сутність понять «компетентність», «мовна компетентність», «мовленнєва компетентність».

Так, у зУ «Про вищу освіту» [1] поняття «компетентність» розкривається як динамічна комбінація знань, вмінь і практичних навичок, способів мислення, професійних, світоглядних і громадянських якостей, морально-етичних цінностей, яка визначає здатність особи успішно здійснювати професійну та подальшу навчальну діяльність і $€$ результатом навчання на певному рівні вищої освіти.

Мовна компетентність - це засвоєння студентом основ науки про мову, її системи. Своєючергою, мовленнєва компетентність пов'язана з мовною і формується на її основі. Тобто самих знань про мову замало для того, щоб нею розмовляти, тому треба фрормувати мовленнєву компетентність.

Мовленнєва компетентність - це готовність і спроможність особистості адекватно й доречно використовувати мову в конкретних ситуаціях буття (висловлювати власні думки, бажання, наміри, прохання тощо), застосовуючи при цьому як мовні, так і позамовні (міміка і жести, рухи) та інтонаційні засоби виразності [8].

В аспекті нашого дослідження під поняттям «мовленнєва компетентність» будемо розуміти практичне володіння державною мовою та основами культури усного і писемного мовлення в різних сорерах спілкування.

Практичне володіння українською мовою передбачає наявність умінь $і$ навичок у різних видах мовної діяльності: аудіювання, читання, переклад, письмо, що дасть змогу робити повідомлення та вести бесіду українською мовою 3 навчальних, суспільно-політичних, наукових та культурно-побутових питань у межах програмної тематики, читати оригінальну літературу за фрахом та перекладати іiі,, писати ресерати, наукові допо- 
віді, анотації, статті, тези, рецензії, відгуки, робити усний та письмовий переклад тощо, оволодіти нормами етики ділового спілкування (об'єктивно фахівець із вищою освітою в перспективі стає лідером, керівником різноманітних виробничих колективів), нормами написання ділових паперів.

Володіння термінологією державної мови за обраним фрахом, науковим та офріційноділовим стилями мови, новими комп'ютернолінгвістичними технологіями є основою мовної підготовки майбутнього фрахівця - головна умова становлення наукового потенціалу України.

Одним із найдієвіших засобів фрормування у студентів мовленнєвої компетентності під час вивчення дисциплін («Українська мова (за профресійним спрямуванням)») вбачаємо застосування ігрових технологій.

Ігрові технології та методи принципово змінюють схему комунікації в навчальному процесі. Вони орієнтовані на реалізацію пізнавальних інтересів і потреб особистості, тому особлива увага приділяється організації процесу есрективної комунікації, в якій учасники процесу взаємодії є більш мобільними, більш відкритими та активними [3].

Ми погоджуємося 3 А. Кабловим та О. Любомирською [2], що інтерактивні технології - це фрорма організації навчального процесу, в якій обов'язковою вимогою виступає взаємодія усіх без виключень учасників такого процесу (виникає ціла система взаємодій: викладач - студент, викладач - аудиторія, студент - аудиторія, студент - студент, аудиторія - аудиторія). При цьому зауважимо, що взаємодія викладача та здобувачів вищої освіти має бути активною та рівноправною, «спрямованою на виховання й навчання під час гри й опанування різних соціальних ролей, 3 метою збагачення індивідуального та суспільного досвіду» [6].

Практичний досвід надав змогу констатувати, що мовленнєва компетентність студентів активно фрормується під час вивчення дисципліни «Українська мова (за професійним спрямуванням)» завдяки таким інтерактивним технологіям: бесіда («Мікрофрон», «Зіпсований телефрон», «Конкурс красномовства»), дискусія («Дерево ухвалення рішень», «Словесний портрет», «Догори ногами»), діалоги («Метод Сократа», «Зміни позицію»), інтерв'ю (інтерв'ювання), дебати, пресконореренції, ток-шоу тощо.

Використання інтерактивних технологій під час підготовки майбутніх фрахівців у ЗВО дало нам змогу виділити низку позитивних моментів:

- гра стимулює студентів до навчання: навіть ті теми, які зазвичай не викликають зацікавленості в студентів, легко засвоюються в ігровій фрормі;

- гра підвищує рівень мовної компетентності студентів: висловитися в невимушеній обстановці має бажання кожен студент;
- гра розвиває самостійність: студенти вирішують складні проблеми, а не залишаються пасивними спостерігачами;

- гра дає змогу зекономити час: студент за гру дізнається більше, ніж за значно більший проміжок часу навчання іншими методами;

- гра допомагає залучити більшу кількість учасників: активна взаємодія в процесі навчання;

- гра створює атмосореру здорового змагання на позитивних емоціях;

- гра підвищує загальний рівень групової згуртованості групи як ціле загалом та ін. [7].

Іншими словами, інтерактивні ігрові технології навчання розвивають мовленнєву компетентність шляхом підвищення зацікавленості до навчання, що, своєю чергою, дає змогу долати перешкоди, які уповільнюють розвиток здатності до комунікації.

Означені види робіт вимагають ретельної попередньої підготовки. Це можуть бути такі завдання: проблемні запитання в рамках завданої теми; тексти монологічного чи діалогічного характеру на завдану тему з відповідними мовленнєвими формулами; завдання до текстів, що сприяють фрормуванню мовленнєвої компетенції, а саме:

- ознайомитися зі сценарієм конореренції й надати загальну характеристику іï проблеми, розповісти про час і місце її проведення, зміст доповідей, використовуючи лексику й фразеологію науково-професійного й офріційно-ділового стилів;

- подати усний короткий огляд цієї конференції;

- назвати й записати типові мовні звороти, що використовуються під час наради;

- дібрати до поданих мовних зворотів синонімічних;

- висловити свою думку з приводу заслуханої на нараді доповіді, поставити запитання доповідачеві;

- на підставі опрацьованого тексту підготувати доповідь $з$ означеної теми тощо [4].

Висновки. Поява нової редакції Українського правопису, а також зУ «Про забезпечення функціонування української мови як державної» активізували дискусії на тему мовного питання в Україні. Де-юре на законодавчому рівні державна мова фрункціонує як у сорері освіти, так і у сорерах послуг, медіа тощо. На практиці ми бачимо, що все не так однозначно, тому використання ігрових технологій навчання дасть змогу сорормувати у студентів мовленнєву компетентність як запоруку практичного володіння державною мовою та основами культури усного і писемного мовлення в різних сорерах і ситуаціях спілкування.

Це дослідження не вичерпує усі аспекти окресленої проблеми, тому потребує детальних наукових розробок та висвітлення отриманих результатів у подальшому. 


\section{БІБЛІОГРАФІЧНИЙ СПИСОК:}

1. Про вищу освіту : Закон України від 09.08.2019p. №1556-VII.URL:https://zakon.rada.gov.ua/ laws/show/1556-18 (дата звернення: 05.10.2019).

2. Каблов А.В., Любомирська О.О. Ігрові інтерактивні методи як важливий інструмент фрормування просесійної компетентності студентів з дисципліни «ннформатика». Молодий вчений. 2017. № 3 (43). C. 386-389.

3. Калініна Л.А., Орлова О.В. Використання ігрових технологій в системі професійної підготовки майбутніх фахівців культурно-дозвіллєвої сфери. Гілея: науковий вісник. 2018. Вип. 139(2). С. 169-173.

4. Лавренюк В.В. Інноваційні і традиційні підходи у викладанні лінгвістичних дисциплін. Перспективні напрями розвитку науки та техніки : матеріали XVIII наук.-практ. конф., м. Вінниця, 23 берез. 2018 р. Вінниця, 2018. С. 34-44.

5. Лопушинський І.П. Забезпечення конституційного статусу державної мови у вищій школі України сьогодення як належна перспектива мовленнєвої фрахової практики. Державне управління: теорія $i$ практика : електрон. наук. фрах. видання НАДУ. 2006. № 1. URL: http:www.nbuv.gov.ua/e-journals/Dutp/ 2006-1/txts/SOCIALNA/06lipmfp.pdf (дата звернення: 18.09.2019).

6. Лугова Т.А., Панькевич О.О. Інтерактивні методи навчання для подолання пізнавально-психологічних бар'єрів під час фрормуванні комунікативних компетентностей майбутніх журналістів. Інфрормаційна освіта та профеесійно-комунікативні технології XXI століття : збірник матер. XII Міжнар. наук.практ. конср., м. Одеса, 11-13 вер. 2019 р. Одеса, 2019. С. $273-288$.

7. Панькевич О.О. Застосування ігрових технологій під час підготовки майбутніх фахівців соціономічної сорери : акмеологічний підхід. Філософрія та гуманізм. Одеса, 2018. Вип. 1 (7). С. 59-65.

8. Формування мовної особистості на різних вікових етапах : монограсрія / за ред. А.М. Богуш, О.С. Трифонова, О. І. Кисельова та ін. Одеса : ПНЦ АПН України, 2008. 272 с. 